\title{
MARKETING ANALYSIS OF SIAMESE CATFISH (Pangasius hypophthalmus) IN THE KUALA KAPUAS FISH MARKET, KAPUAS DISTRICT, CENTRAL KALIMANTAN PROVINCE
}

\author{
Daniar Unget ${ }^{1}$, Emmy Sri Mahreda ${ }^{2}$ and Emmy Lilimantik ${ }^{2 *}$ \\ ${ }^{1}$ Student of Magister Program of Fishery, University of Lambung Mangkurat, Indonesia \\ ${ }^{2}$ Faculty of Fishery and Marine, University of LambungMangkurat, Indonesia \\ $2 *$ Corresponding author: Emmy Lilimantik \\ https://doi.org/10.35410/IJAEB.2020.5500
}

\begin{abstract}
This study aims to determine how the marketing system of Siamese Catfish (Pangasius hypophthalmus) in the Kuala Kapuas fish market. The analysis used is (1) marketing channels using the snowball sampling method (2) marketing margins (3) Farmer's share, and (4) market structure using analysis (a) price transmission elasticity and (b) market integration. The analysis shows that (1) Siamese catfish marketing channels consist of 3 marketing channels, (2) Total marketing margin on marketing channel 1 is Rp. 2,700, -, marketing channel 2 is Rp. 6,700, and channel 3 is Rp. 8,973 (3) The share of prices received by producers in channel 1 is $73.20 \%$, in marketing channel 2 is $87.14 \%$, and in marketing channel 3 is $67.10 \%$ and (4) analysis of market structure is known that (a) the analysis result of price transmission elasticity $(\eta)$ in marketing channel 1 and marketing channel 2 is 0.130 and marketing channel 3 is 0.169 , which means the price change is less elastic. (b) the results of market integration analysis obtained the regression coefficient $(\square)$ of 0.1134 which indicates that the market structure is oligopsonistic.
\end{abstract}

Keywords: Siamese Catfish, Marketing Channels, Marketing Margins, Farmer's Share, and Price Transmission Elasticity and Market Integration.

\section{INTRODUCTION}

Kapuas Regency with an area of 14,999 Km2, has inland water areas which include lakes, swamps and several major rivers including the Kapuas Murung River $(+66.38 \mathrm{Km})$, Kapuas River $(+600.00 \mathrm{Km}$ ), while the coastal / coastal area has a length of $+189.85 \mathrm{Km}$. (Kapuas District Fisheries Service, Kapuas Regency Minapolitan Area Development Report 2016). 
Table 1. Number of Aquaculture Fisheries Production from 2014 - 2018 Kapuas Regency

\begin{tabular}{|llrrrrrr|}
\hline \multirow{2}{*}{ No } & Fish Type & Sat & \multicolumn{5}{c}{ Year } \\
\cline { 5 - 8 } 1. & Patin siam & Ton & $5.512,69$ & $7.939,78$ & $8.707,41$ & $11.019,36$ & $10.348,33$ \\
2. & Gabus & Ton & 86,19 & 72,52 & 98,10 & 74,89 & 83,72 \\
3. & Toman & Ton & 33,45 & 34,88 & 37,89 & 64,25 & 80,23 \\
4. & Betok & Ton & 24,31 & 17,84 & 42,63 & 91,86 & 63,50 \\
5. & Nila & Ton & 665,73 & 644,11 & 752,63 & 250,62 & 314,67 \\
6. & Lele & Ton & 283,30 & 329,32 & 341,22 & 77,22 & 105,17 \\
7. & Gurame & Ton & 109,08 & 112,55 & 120,54 & 42,46 & 20,40 \\
8. & Bawal & Ton & 32,72 & 31,10 & 35,48 & 10,36 & - \\
9. & Bandeng & Ton & $2.930,82$ & $3.050,64$ & $3.375,72$ & $1.793,95$ & $1.867,94$ \\
10. & Udang api-api & Ton & $1.462,08$ & 902,94 & 986,87 & $1.192,93$ & $1.896,65$ \\
\hline
\end{tabular}

Source: Kapuas District Fisheries Service Annual Report, 2019

Table 1 explains that the production of Siamese catfish occupies the top production of other commodities in 2017 amounting to 11,019.36 tons but there was a decrease in 2018 of 10,348.33 tons this is due to an increase in factory feed prices and also artificial feed raw materials such as bran, coconut cake, trash fish has also increased so there are several groups of farmers whose members temporarily stop running their businesses.

The Kuala Kapuas fish market located on the Mawar Kuala Kapuas road is a marketing center for fishery commodities both sourced from aquaculture and fishing activities. The marketing transaction starts at $02.00-06.00 \mathrm{am}$, it can be known by the collectors, retailers and consumers to make a purchase transaction. Based on the data of respondents to collectors who sell to retailers and consumers the needs of catfish sold in one day 3.5 - 4 tons, this shows the high interest of the public to consume catfish and the price is affordable.

Production of catfish culture in the Kapuas Regency is very large, this can be seen in the fulfillment of the needs of catfish in the local market in Kuala Kapuas, as well as the many requests from various cities such as Palangkaraya, Sampit and Pangkalanbun. Production of catfish in sub-districts (tons) in 2014-2018 Kapuas Regency is presented in Table 2. 
Table 2. Production of Catfish Cultivation (ton) Per District in 2014 - 2018 Kapuas Regency

\begin{tabular}{|c|c|c|c|c|c|}
\hline Districts & & & $\operatorname{ar}$ (Ton) & & \\
\hline No & 2014 & 2015 & 2016 & 2017 & 2018 \\
\hline 1. Kapuas Kuala & 523,71 & 941,79 & $1.480,26$ & $1.873,29$ & $1.786,33$ \\
\hline 2. Chess Chart & 273,03 & 635,89 & 565,98 & 716,26 & 653,56 \\
\hline 3. Kapuas Timur & 65,20 & 92,06 & 280,38 & 517,91 & 645,56 \\
\hline 4. Bataguh & 340,05 & 779,61 & 957,82 & $1.212,13$ & $1.205,34$ \\
\hline 5. $\quad$ Strait & $1.915,98$ & $1.949,39$ & $1.271,28$ & $1.608,83$ & $1.493,66$ \\
\hline 6. $\quad$ Basarang & $1.656,26$ & $1.909,75$ & $2.647,13$ & $1.983,48$ & $1.832,96$ \\
\hline 7. Kapuas Hilir & 105,34 & 247,45 & 435,37 & 550,97 & 464,62 \\
\hline 8. Petak Island & 55,59 & 289,65 & 391,83 & 495,87 & 423,18 \\
\hline 9. Kapuas Murung & 231,37 & 265,95 & 583,40 & 738,30 & 666,64 \\
\hline 10. Bye & 18,98 & 93,18 & 174,15 & 220,39 & 196,24 \\
\hline 11. Kapuas Barat & 127,69 & 325,25 & 426,66 & 528,93 & 534,88 \\
\hline 12. Mantangai & 25,91 & 156,75 & 217,69 & 275,48 & 197,00 \\
\hline 13. Overflow & 102,53 & 120,59 & 189,82 & 220,39 & 188,42 \\
\hline 14. Kapuas Tengah & 71,05 & 132,46 & 165,44 & 46,28 & 32,08 \\
\hline 15. Talawang Stake & - & - & - & - & - \\
\hline 16. Kapuas Hulu & - & - & - & 27,55 & 25,10 \\
\hline 17. Mandau Talawang & - & - & - & 3,31 & 3,80 \\
\hline Total & $5.512,69$ & $7.939,77$ & $8.707,41$ & $11.019,36$ & $10.348,89$ \\
\hline
\end{tabular}

Source: Kapuas District Fisheries Service Annual Report, 2019

Table 2 explains that the cultivation of catfish commodity fisheries from 2014-2018 there was a significant increase and distribution of catfish marketing from various districts in the Kapuas Regency. The catfish sold in the Kapuas Kuala fish market do not have price differences with several adjacent districts because of its proximity to the production area, but for other distant 
districts such as Kapuas Tengah District, Tabah District, Pasak Talawang District, Mandau Talawang District the price is relative high because the location is far from the production area.

The high price of catfish is still the main attraction for producers and traders to sell fish to the main markets in several regions in the Kapuas Regency. The high price at the producer level will have a positive impact, this is because the profits obtained by producers will be even greater and will stimulate producers to increase the amount of production (Lilimantik, 2011). The price of catfish in Kapuas Regency from January to December 2018

Table 3. Price of Siamese Patin Fish in Kapuas District in 2018

\begin{tabular}{|clccc|}
\hline No & Month & \multicolumn{3}{c|}{ Price } \\
\cline { 3 - 5 } & & $\begin{array}{c}\text { Manufacturer } \\
(\mathrm{Rp})\end{array}$ & Collector (Rp) & Retailer (Rp) \\
\hline 1 & January & 18.000 & 20.000 & 25.000 \\
\hline 2 & February & 18.000 & 20.000 & 25.000 \\
\hline 3 & March & 18.500 & 20.500 & 25.500 \\
\hline 4 & April & 19.500 & 21.500 & 26.500 \\
\hline 5 & May & 20.000 & 22.000 & 27.000 \\
\hline 6 & June & 19.500 & 21.500 & 26.500 \\
\hline 7 & July & 19.500 & 21.500 & 26.500 \\
\hline 8 & August & 20.500 & 22.500 & 27.500 \\
\hline 9 & September & 21.000 & 23.000 & 28.000 \\
\hline 10 & October & 21.500 & 23.500 & 28.500 \\
\hline 11 & November & 20.500 & 22.500 & 27.500 \\
\hline 12 & December & 22.000 & 24.000 & 29.000 \\
\hline
\end{tabular}

Source: 2019 Kapuas District Fisheries Service Data Report

Anindita and Baladina (2017), explained that in an efficient market structure, the slightest change in price that occurs in a market will cause price to fluctuate. Prices at the retail level will be the basis for determining the price to be paid to intermediary traders and ultimately to producers and vice versa. Furthermore, the price received by farmers will be a determinant of how much volume of production produced by producers to be sold to intermediary traders or retailers. If the price received is satisfactory, the production offered to the market will increase, 
and vice versa (Hanafiah and Saefuddin, 1996). Increased production is expected to meet consumer demand so that catfish can be distributed evenly in all regions.

\section{LITERATURE REVIEW}

Consumer interest in catfish is very high considering the price is relatively affordable and available at any time not based on the season. Catfish is distributed to several markets quickly and on target is strongly influenced by the pattern of its marketing channels. Marketing channels help in the transfer of rights to goods or services while moving from producers to consumers (Irawan and Soedjono, 2001). According to Sudiyono (2002), existing marketing channels certainly involve marketing institutions in which marketing institutions are business entities or individuals who conduct marketing require services and commodities from producers to end consumers and have links with business entities or other individuals. This marketing agency arises because the desire of consumers to obtain commodities in accordance with the time and place that consumers want.

The marketing of fish and other aquatic products is a very important and crucial chain of activities between fishermen / fish farmers and consumers. Marketing efforts can play a role in forming prices, absorbing production, increasing quality, increasing modernization, motorizing fisheries, increasing income and producing welfare. (Eddiwan, (1983).

The concept of marketing is an overall system of business activities aimed at planning, determining prices, promoting goods and distributing goods and services that can satisfy the needs of consumers (Limbong and Sitorus (1987).

The longer the marketing chain, the greater the marketing costs, this results in more marketing margins, so that the share of the price received by farmers will be smaller. The small part of the price received by fishermen will cause a lack of encouragement for fishermen to produce more (Kohls and Uhl, 2002). Marketing efficiency of fishery products is a form of fish marketing system that occurs briefly from the level of fishermen / fish cultivators to the level of end consumers. With marketing margins as low as possible, prices at the level of fishermen / fish farmers are higher and can provide a reasonable level of profit for each marketing institution involved in it, so as to provide a fair share of all prices paid by consumers without reducing consumer satisfaction (Mahreda, 2002).

The length of a marketing channel can affect its margins, the longer the marketing channel, the greater the marketing margins, because more and more marketing institutions are involved. The large number of marketing margins can cause the portion of prices received by producers to be smaller than the prices paid by consumers directly to producers, so that marketing channels that occur or are longer can be said to be inefficient (Istiyanti, 2010). In line with opinions (Limbong and Sitorus, 1987). One indicator to look at the efficiency of marketing activities is by comparing the portion of prices received by farmers to the prices paid by end consumers, the share of prices received by marketing institutions is often expressed as a percentage value

To see the relationship of price elasticity at the consumer level, it can be seen that the transmission price elasticity is the relative change of retail prices to the change in relative prices 
at the producer level The price transmission elasticity is used to explain the comparison of the percentage change in price at the retail level with the percentage change in price at the producer level. (Azzaino, 1982). Markets that are integrated both spatially and intertemporally can identify that marketing inefficiencies occur resulting in price games and price distortions in the market (Barrett, 2005). This is in line with the opinion of Anindita (2004), that the weak market structure is a consequence of weak market integration, difficulty in information and trade flows between separate markets. An integrated market identifies an efficient marketing system (Fadhla, 2008). According to Feckler and Goodwin (2001) market integration is the level of price movements in different regions, where the same product will have the same price, even if sold in different places and Price signals and market information are transmitted equally.

\section{RESEARCH METHODS}

\subsection{Place of Research}

The research location was determined intentionally (purposive sampling), namely in the Kuala Kapuas fish market, Kapuas Regency, Central Kalimantan Province. With the consideration that in that market the most fish commodity sales were catfish.

\subsection{Sample Determination}

The population observed included fish farmers and marketing institutions which included collecting traders and retailers. The sampling method for catfish farmers uses the simple random sampling method, which is a sampling method where members of the population have the same opportunity to be selected as a sample (Sugiarto et al, 2003). Samples of fish cultivator respondents for three locations are 30 people, where each village / village is represented by 10 people assuming that there are many regions empower catfish. Sample Market Traders as many as 4 people and market retailers and village retailers as many as 30 people were determined using the snowball sampling method by traversing the marketing institutions gradually.

The data used are primary data and secondary data, primary data is data that is observed, recorded and obtained directly from the source for the first time (Marzuki, 2002). Data collection techniques (samples) use survey and interview methods. Surveys are studies that take samples from a population and use questionnaires as a primary data collection tool (Singarimbun and Effendi, 1985). While the interview according to Nazir (1983), is the process of obtaining information for research purposes by asking respondents directly. Secondary data is data that has been available in various forms both in the form of statistical data or data that is processed, available and ready at relevant agencies that are relevant to the research conducted (Daniel, 2003).

\subsection{Data Analysis}

\subsubsection{Marketing Channel Patterns}

The analysis used is qualitative to look at the marketing channel of catfish in the Kuala Kapuas fish market which is formed from the level of producers (fish farmers), collectors, retailers and end consumers. The technique of determining the sample is using snowball sampling. According 
to Sugiyono (2005), snowball sampling is a technique for determining the sample at first in small numbers, then this sample is told to choose his friends to be sampled and so on, so that the number of samples increases.

\subsubsection{Marketing Margin Analysis}

Marketing margin is the difference between the purchase price of the producer and the collector and retailer against the retail price. For the marketing margin analysis of each marketing channel pattern, it is calculated using the formula according to Tomek and Robinson (1981):

$$
\mathrm{MP}=\mathrm{Pr}-\mathrm{Pf}
$$

Information :

MP $=$ Marketing Margin

$\operatorname{Pr}=$ Price at retail level

$\mathrm{Pf}=$ Price at the level of fish farmers

\subsubsection{Farmer's Share}

One indicator to look at the efficiency of marketing activities is by comparing the share of prices received by farmers against the prices paid by end consumers, the share of prices received by marketing institutions is often expressed as a percentage value (Limbong and Sitorus, 1987). The share of prices received by fish farmers (Fs) from retailers is calculated using the following model (Kohls and Uhl, 2002)

$$
F s=\frac{P f}{P r} \times 100 \%
$$

Information :

$$
\begin{aligned}
& \mathrm{Fs}=\text { the share of the price received by fish farmers }(\%) \\
& \mathrm{Pf}=\text { Price at fish farm level }(\mathrm{Rp} / \mathrm{kg}) \\
& \mathrm{Pr}=\text { Price at retailer / consumer trader }(\mathrm{Rp} / \mathrm{kg})
\end{aligned}
$$

To find out the efficiency or not the price part received by fish farmers can be seen from the percentage of the results of the above calculation, namely;

- If the share is $>50 \%$ then the price part is called efficient

- If the share $<50 \%$ then the price part is not efficient

\subsection{Market Structure Analysis}




\subsubsection{Price Transmission Elasticity}

Price transmission elasticity is used to determine the relationship between prices at the producer level and prices at the end consumer. The price transmission elasticity is formulated as follows (George and King, 1971):

$$
\eta=\boldsymbol{\beta} \frac{\mathbf{P r}}{\mathbf{P f}}
$$

Information :

$\eta=$ Price transmission elasticity

$\beta=$ Regression coefficient

$\operatorname{Pr}=$ price at the consumer level

$\mathrm{Pf}=$ price at producer level

Assessment criteria :

1. If $\beta<1$, it means that a $1 \%$ price change at the consumer level will result in a price change of less than $1 \%$ at the producer level.

2. If $\beta=1$, it means that a $1 \%$ price change at the consumer level results in a $1 \%$ change at the producer level.

3. If $\beta>1$, it means that a $1 \%$ price change at the consumer level results in a price change $>1 \%$ at the producer level.

\subsubsection{Market Integration Analysis}

Market integration uses regression analysis with the assumption that if the prices of other factors are fixed, prices at producer level $(\mathrm{Pf})$ and prices at consumer level $(\mathrm{Pr})$ are linear, the equation model is as follows (Azzaino, 1982):

$$
\mathbf{P f}=\alpha+\beta \text { Pr }
$$

The regression coefficient between $\mathrm{Pf}$ and $\mathrm{Pr}$ is:

$$
\boldsymbol{\beta}=\frac{\sum \mathbf{P r} . \mathbf{P f}-\left(\sum \mathbf{P r} \cdot \sum \mathbf{P f}\right) / \mathbf{n}}{\left(\sum \mathbf{P r}^{2}-\left(\sum \mathbf{P r}\right)^{2} / \mathbf{n}\right)\left(\sum \mathbf{P f}^{2}-\left(\sum \mathbf{P f}\right)^{2} / \mathbf{n}\right)}
$$

Information :

$\operatorname{Pr}=$ retail price

$\mathrm{Pf}=$ Price at producer

$\mathrm{n}=$ Number of samples

$\alpha=$ Interception

$\beta=$ Regression coefficient 
Assessment criteria :

1. If $\beta<1$, the market structure is monopsonic or oligopsonic because the increase in the price of one unit at the retailer level is followed by a price increase that is smaller than one unit at the level of the cultivator (producer).

2. If $\beta>1$, then the market structure is monopolistic or oligopoly because an increase in the price of one unit at the retailer level is followed by a price increase that is greater than one unit at the level of the cultivator (producer).

3. If $\beta=1$, then the market structure is perfect competition which means the formation of intermarket prices is more integrated units in other words the increase in the price of one unit at the retailer level is followed by the increase in the price of one unit at the level of the cultivator (producer).

\section{RESULTS AND DISCUSSION}

\subsection{Marketing Channel Pattern}

Based on the research conducted, the marketing channel for Siamese catfish in the Kuala Kapuas fish market was obtained:

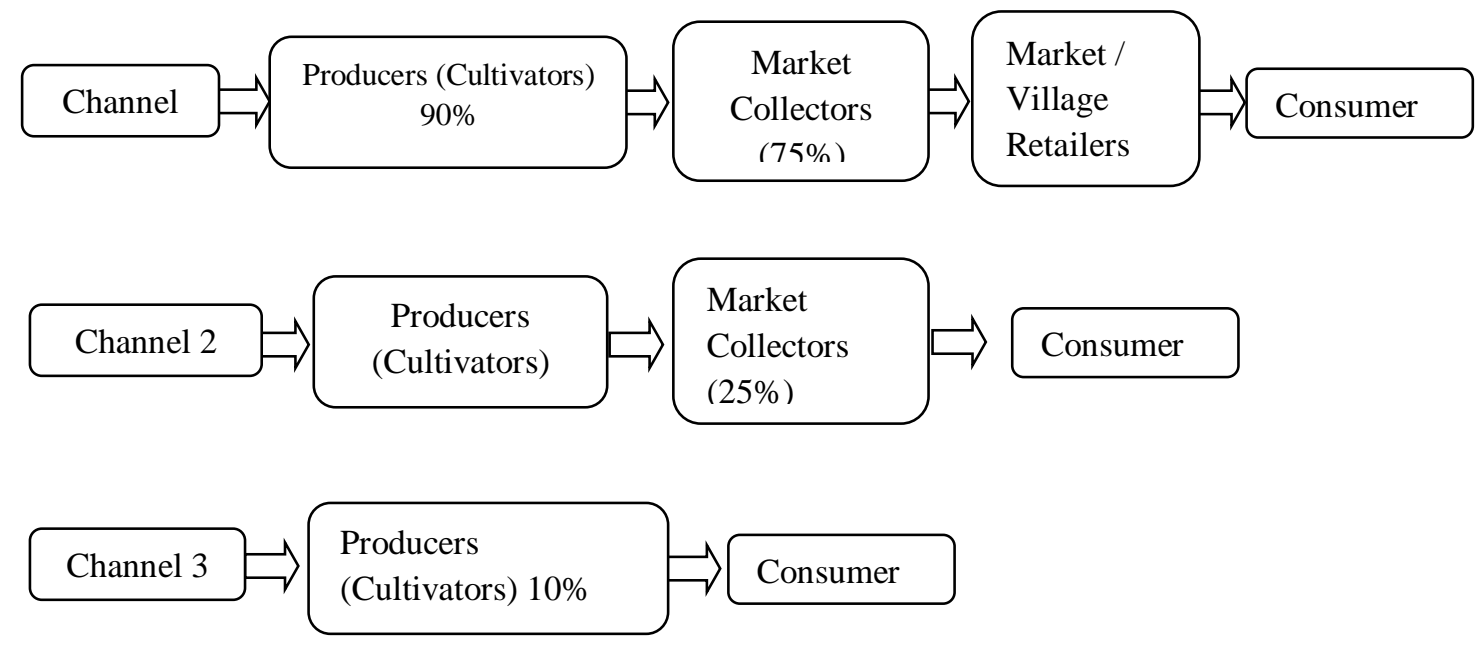

Figure 1. Marketing Channel Pattern

Figure 1 explains that there are 3 patterns of catfish marketing channels that exist in the Kuala Kapuas fish market, but the most are in channel 1 pattern with the reason that:

a. Producers (cultivators) sell catfish harvest directly because there is cooperation in the marketing institute that is run.

b. Collector traders are in the production area, making it easier and have a marketing relationship between the products produced by producers.

c. Collector traders already collaborate with retailers. 
d. Retailers marketing fishery products are regular customers

\subsection{Marketing Margin}

Table 4. Prices at Cultivator level (Pf), Prices at the Market / Village (Pr) level, and Marketing Margin Value in the Siamese catfish marketing channel.

\begin{tabular}{|ccccc|}
\hline $\begin{array}{c}\text { Marketing } \\
\text { Channel }\end{array}$ & $\begin{array}{c}\text { Pf } \\
(\mathrm{Rp})\end{array}$ & $\begin{array}{c}\text { (Rp) Pr } \\
\text { Market }\end{array}$ & $\begin{array}{c}\text { (Rp) Village } \\
\text { Pr }\end{array}$ & (Rp) MP \\
\hline 1 & 18.300 & 21.000 & & 2.700 \\
\hline 2 & 18.300 & 25.000 & & 6.700 \\
\hline 3 & 18.300 & - & 27.273 & 8.973 \\
\hline
\end{tabular}

Source: Primary data processed (2019)

Table 4 explains that the biggest marketing margin is channel 3, which is Rp. 8,973 with the reason that the profits are greater than channels 1 and 2 because the producers themselves directly sell catfish to consumers.

\subsection{Farmer's Share}

Farmer's Share is part of the price received by the producer (cultivator) with a share of the price in the final consumer. The results show based on the following table 5.

Table 5. Farmer's Share received by producers (cultivators) of Siamese catfish from Maluen Village, Panamas Village and West Selat Village

\begin{tabular}{|cccc|}
\hline $\begin{array}{c}\text { Saluran } \\
\text { Pemasaran }\end{array}$ & $\begin{array}{c}\text { Prices at producer } \\
\text { level }(\mathrm{Rp} / \mathrm{kg})\end{array}$ & $\begin{array}{c}\text { Price at the Consumer } \\
\text { level }(\mathrm{Rp} / \mathrm{kg})\end{array}$ & Farmer share $(\%)$ \\
\hline 1 & $18.300,-$ & $25.000,-$ & 73,20 \\
\hline 2 & $18.300,-$ & $21.000,-$ & 87,14 \\
\hline 3 & $18.300,-$ & $27.273,-$ & 67,10 \\
\hline
\end{tabular}

Source: Primary data processed (2019)

Table 5 shows the farmer's share in the marketing channel (1) by $73.20 \%$, the marketing channel (2) by $87.14 \%$ and the marketing channel (3) by $67.10 \%$. According to the farmer's share criteria of the three marketing channel patterns is greater than $50 \%$ so everything can be said to be efficient.

\subsection{Structure, Conduct and Performance}

\subsubsection{Price Transmission Elasticity}

The elasticity of price transmission is done to see the sensitivity of price changes at the producer level as a result of price changes in the consumer's mind. Price at producer level (Pf), Price at retail level (Pr), Regression Value $(\beta)$ and Transmission Elasticity Value of each marketing channel in the following table 6 : 
Table 6. Prices at the Producer Level (Pf), Prices at the Retailer Level (Pr), Regression Values $(\beta)$ and Value Transmission Elasticity for each Marketing Channel

\begin{tabular}{|ccccc|}
\hline $\begin{array}{c}\text { Channel } \\
\text { Marketing }\end{array}$ & $\begin{array}{c}\text { Pr } \\
(\mathrm{Rp})\end{array}$ & $\begin{array}{c}\text { Pf } \\
(\mathrm{Rp})\end{array}$ & $\beta$ & ET \\
\hline 1 & 21.000 & 18.300 & 0,1134 & 0,130 \\
\hline 2 & 21.000 & 18.300 & 0,1134 & 0,130 \\
\hline 3 & 27.273 & 18.300 & 0,1134 & 0,169 \\
\hline
\end{tabular}

Source: Primary data processed (2019)

Table 6. Explaining the Price Transmission Elasticity between prices at the producer level and prices at the retail level at each marketing channel are Marketing Channel 1 (one) and Marketing Channel 2 (two) at 0.130 and Marketing Channel 3 (three) at 0.169. ET value is less than one ( $\eta$ $<1$ ), that is 0.130 and 0.169 , this value indicates that if there is a price change of $1 \%$ at the consumer level it will cause a price change of $0.130 \%$ and $0.169 \%$ at the producer level, meaning that the elasticity of price transmission is less elastic. The small elasticity value indicates that the collecting trader plays a role in determining the price to the producer (the cultivator) in this case the power of the buyer from the producer is not determined by the producers themselves but by the collecting traders.

\subsubsection{Market Integration Analysis}

Based on the regression analysis of Siamese catfish prices at the level of farmers and at the level of retailers, it can be seen in Table 7 .

Table7 Results of Regression Analysis Prices at the Producer (Pf) level and Prices at the Retailing Level (Pr) of the Siamese catfish marketing channel at the Kuala Kapuas Fish Market.

\begin{tabular}{|lcc|}
\hline No & Coefficient & Score \\
\hline 1. & $\alpha$ & 1.5371 \\
\hline 2. & $\beta$ & 0,1134 \\
\hline 3. & $\mathrm{r}$ & 0,4005 \\
\hline 4. & $\mathrm{R}^{2}$ & 0,1604 \\
\hline 5. & P-Value & 0,0283 \\
\hline
\end{tabular}

Source: Primary data processed (2019)

The results of regression analysis of Siamese catfish prices at the level of farmers and at the level of retailers obtained a value of $\beta<1$ meaning an increase in price of Rp. 1, - at the retail level followed by a price decline of Rp. .1134 at the producer level. This shows that the marketing structure of Siamese catfish in the Kuala Kapuas fish market is a market that is not perfectly integrated, meaning that the market is not perfectly integrated where producers (cultivators) are more numerous and buyers are fewer collecting traders, the shape of the market structure leads to the oligopsonistic market. 


\section{CONCLUSIONS AND RECOMMENDATIONS}

\subsection{Conclusion}

The results of the research conducted can be concluded :

1. The marketing channel for Siamese catfish (Pangasius hypophthalmus) at the Kuala Kapuas fish market involves several marketing institutions, namely producers (cultivators), collectors, retailers and consumers consisting of (1). Marketing 1: Producers (cultivators), Market collectors, Market retailers / Village Retailers, Consumers, (2). Marketing 2: Producers (farmers), market traders, consumers, (3). Marketing 3: Producers (cultivators), Consumers.

2. Marketing margin on Marketing Channel 1 (one) based on the purchase and sale price received by the collecting traders is Rp. 2,700. Marketing margins in Marketing Channel 2 (two) based on the purchase and sale prices received by retailers at the market level of Rp. 2,700. Marketing margin in the 3 (three) marketing channels based on the purchase and sale prices received by retailers at the village level is $\mathrm{Rp} .8,973$.

3. The share of prices received by producers in the marketing channel (1) is $73.20 \%$, the marketing channel (2) is $87.14 \%$ and the marketing channel (3) is $67.10 \%$. According to the farmer's share criteria all three marketing channel patterns are greater than $50 \%$ so they can be said to be efficient.

4. Elasticity of Transmission Prices between prices at producer level and prices at retail level at each marketing channel are Marketing Channel 1 (one) and Marketing Channel 2 (two) at 0.130 and Salauran Marketing 3 (three) at 0.169 . The value of price transmission elasticity is less than one $(\eta<1)$ that is equal to 0.130 and 0.169 this value indicates that if there is a price change of $1 \%$ at the consumer level it will cause a price change of $0.130 \%$ and $0.169 \%$ at the producer level, meaning that the price transmission elasticity is less elastic. The small elasticity value indicates that the collecting trader plays a role in determining the price to the producer (the cultivator) in this case the power of the buyer from the producer is not determined by the producers themselves but by the collecting traders.

5. Based on the regression analysis of Siamese catfish prices at the level of farmers with prices at the level of retailers obtained $\beta<1$ value means an increase in price of $\mathrm{Rp}$. 1, - at the retail level followed by a price decrease of Rp. 9,1134 at the producer level. This shows that the marketing structure of Siamese catfish in the Kuala Kapuas fish market is not a fully integrated market, meaning that where producers (farmers) are more numerous and buyers are fewer collecting traders, the shape of the market structure leads to the oligopsonic market.

\subsection{Suggestions}

1. To increase producer profits, producers should be involved in determining prices.

2. The large marketing margins received by producers (farmers) are expected to improve welfare and business activities will continue. 
3. Farmer's Share received by producers (farmers) can be said to be efficient from the three marketing channels, but prices at the level of farmers need to be increased again to offset the costs in the catfish cultivation business that is carried out.

4. Value of Price Transmission Elasticity $(\eta<1)$, namely channel I, II of 0.130 and channel III of 0.160 based on this value Price Transmission Elasticity is less elastic, it would be nice if the value $(\eta=1)$ so that the market becomes elastic.

5. It is expected that the market structure is perfectly integrated so that prices can be balanced against production costs.

\section{REFERENCE}

Anindita Ratya, 2004. Marketing of Agricultural Products. Papyrus. Surabaya.

Anindita and Baladina, 2017. Agricultural Product Marketing. PT. ANDI, Yogyakarta. $304 \mathrm{p}$

Azzaino, 1982. Introduction to Agricultural Trading. Agriculture department. Agricultural Social Economic Sciences. IPB, Bogor.

Barret, C. 2005. Measuring Integration and Effiency in the International Agricultural Market. Review of Agricultural Economics. 23 (1): 19-32.

Daniel, M. 2003. Socio-Economic Research Methods. Earth Literacy. Jakarta.

Kapuas District Fisheries Service. 2016, Kapuas District Minapolitan Area Development Report

Kapuas District Fisheries Service, 2019. Annual Report of the Kapuas District Fisheries Service.

Eddiwan. 1983. The Role of Cooperatives in Marketing Products and Fishermen Village Development. Fisheries Research and Development Center. Jakarta 150 Pages.

Emmy Sri Mahreda, 2002. Efficient Marketing of Fresh Sea Fish in South Kalimantan. Doctoral Dissertation of Doctoral Program at Gajah Mada University. Yogyakarta. 366 Pages.

Feckler, Paul L. And Goodwin, Barry K. 2001. Spatial Price Analysis. Department of Agricultural \& Economic Resources. North Carolina State University. Raleigh. NC.

Fadhla, T, B.A. Nugroho and M.M. Efficacious. 2008. Integration of the Food Commodity Market (Rice, Peeled Peanuts and Yellow Soybeans) in the Province of Nanggroe Aceh Darussalam. Agritek Vol. 16 No.9.

George and King, 1971. Consumer Demand for Food Comodities in the United States with Projects for 1980. Gianini Foundation Monograph No. 26, March 1971.

Hanafiah and Saefuddin, 1996. Fisheries Product Administration. UI Press Publisher, Jakarta. 
Irawan and Soedjono, 2001. Marketing, Principles and Cases. Yogya. BPFE

Istiyanti Eni, 2010. Journal of Efficient Curly Red Chili Marketing in Ngemplak District, Sleman Regency. Mapeta, 12 (2) 116-124.

Kohls, R. L. and J. N. Uhl. 2002. Marketing of Agricultural Products. A Prentice-Hall Upper Saddle River, New Jersey.

Lilimantik, 2011. Structure, Behavior and Appearance of the Carp Fish (Cyprinus carpio) Business Market in Karamba in Banjar District, South Kalimantan Province. Journal of Sustainable Development and Sustainable Nature Vol. 1 No. February 2, 2011.

Limbong, W. H. and Sitorus, P. 1987. Introduction to Agricultural Business Administration Department of Agricultural Social Economic Sciences. IPB Agriculture Faculty. Bogor.

Marzuki, 2002. Research Methodology. Visual Basic 6.0 database with Crystal Report-BPFE UII. Andi Yogyakarta. Yogyakarta.

Nazir, 1983. Scientific Research Methods, Ghalia Indonesia Jakarta.

Singarimbun, M and Effendi, S., 1985. Survey Research Methods, Jakarta.

Sudiyono, 2002. Agricultural Marketing. Publisher of the University of Muhammadiyah Malang.

Sugiarto et al, 2003. Sampling Techniques. Gramedia Main Library. Jakarta.

Sugiyono.2005. Administrative Research Methods. Alfabeta Publisher, Bandung

Tomek W. G and Robinson K. L, 1981. Agricultural Product Price. Cornell University Press. London. 